\title{
A study about microbiological quality and species identification of frozen turkey meat
}

\author{
Aydın Vural", Mehmet Emin Erkan, Husnu Sahan Guran, Halil Durmusoglu \\ Department of Food Hygiene and Technology, University of Dicle, Faculty of Veterinary Medicine, Diyarbakır, Turkey
}

\section{Email address:}

avural@dicle.edu.tr (A. Vural)

\section{To cite this article:}

Aydın Vural, Mehmet Emin Erkan, Husnu Sahan Guran, Halil Durmusoglu. A Study about Microbiological Quality and Species Identification of Frozen Turkey Meat. International Journal of Nutrition and Food Sciences. Vol. 2, No. 6, 2013 , pp. $337-341$. doi: $10.11648 /$ j.ijnfs.20130206.22

\begin{abstract}
The aim of this study was to identify potential health risks and evaluate the microbiological quality of frozen turkey meat sold in Diyarbakır, Turkey. In this study, a total of 110 frozen turkey meat samples were collected from retail markets in the city of Diyarbakır. The samples were analyzed by using standard analysis methods for total mesophilic aerobe bacteria, coliform bacteria, Escherichia coli, Staphylococcus-Micrococcus spp., Yersinia enterocolitica, sulfite reducing anaerobe bacteria, mould\&yeast, Salmonella spp. and Listeria monocytogenes. Detection of meat species samples were determined by ELISA. The mean counts of microorganism in the frozen turkey meat which were analyzed, total mesophilic aerobe bacteria were found as $9.5 \times 10^{6} \mathrm{cfu} / \mathrm{g}$, coliform bacteria as $2.7 \times 10^{4} \mathrm{cfu} / \mathrm{g}$, Escherichia coli as $1.1 \times 10^{3}$ $\mathrm{cfu} / \mathrm{g}$, Staphylococcus-Micrococcus spp. as $3.4 \times 10^{4} \mathrm{cfu} / \mathrm{g}$, Yersinia enterocolitica as $3.3 \times 10^{4} \mathrm{cfu} / \mathrm{g}$, sulfite reducing anaerobe bacteria as $4.5 \times 10^{1} \mathrm{cfu} / \mathrm{g}$, mould\&yeast as $2.2 \times 10^{4} \mathrm{cfu} / \mathrm{g}$. The existence of Salmonella spp, and Listeria monocytogenes in the examined samples were found as $3.63 \%$ and $17.27 \%$, respectively. All samples analyzed were found to be turkey meat. In conclusion, this study demonstrates that some pathogens, including Salmonella spp., L. monocytogenes, E. coli and Yersinia enterocolitica are present in frozen turkey meat. Also, the presence of these organisms indicated that there were poor hygienic conditions during the slaughtering, packaging, storage and sales process. Therefore, this food is a serious risk to the public health. Temperature control also is a key issue in producing frozen turkey meat. In addition, it is also important that the products must be manufactured under good hygienic practices.
\end{abstract}

Keywords: Turkey Meat, Microbiological Quality, ELISA

\section{Introduction}

The poultry meats including the turkey meat among the food of animal origin are preferred to red meat because they have low level of cholesterol and high level of protein/calorie for health purposes. In addition, turkey meat is rich in terms of $\mathrm{B}$ group of vitamins, thiamin (B1), riboflavin (B2), niasine (B3) and pyridoxine (B6), and for mineral stuff calcium, phosphor and potassium [1-4].

Since there exist pathogen microorganisms widely, and these can spread over the flog rapidly, turkey meet should also be taken into account for food-borne illnesses. The main bacterial infection and intoxication factors arising from turkey meat are Salmonella spp., Listeria monocytogenes, Campylobacter jejuni, Staphylococcus aureus and Clostridium perfringens. From poultry farm to table in all the stages, in case of not taking the required protective provisions, microorganisms and contamination can be formed, and due to these contaminated factors, consumption of turkey meat may cause infections and intoxication [2]. Despite the several studies conducted to determine the hygienic quality of the red meat and poultry meats, there are not sufficient number of studies to determine the food safety and public health risk dimensions of turkey meat and turkey products which have been produced to a large extent in recent years [5].

Through this study, our aim is to determine the microbiological quality and to evaluate the risks in terms of public health of the frozen turkey meats put on sale into Diyarbakır markets. Furthermore, through ELISA method, identification of species was made in the samples put into sales as turkey meat and existence of different species was also investigated. 


\section{Materials and Methods}

\subsection{Collecting the Samples}

Frozen turkey meats put into sale in Diyarbakır City, Turkey, were collected and immediately brought into the laboratory keeping their storage temperatures and without letting they dissolved, followed by analysis.

\subsection{Microbiological Analyses}

In the process of microbiologic analyses of turkey meat samples, $10 \mathrm{~g}$ sample taken under aseptic conditions was homogenized by using $90 \mathrm{ml}$ of $0.1 \%$ peptone water. Following preparation of decimal dilutions, the appropriate medium was inoculated by standard analysis methods.

For the count of total mesophilic aerobic bacteria (TMAB), Plate Count Agar (Merck 1. 05463) was inoculated by using pour plate method and reproduced colonies were counted after 48 hours of incubation at $37^{\circ} \mathrm{C}$ [6]. Violet Red Bile Agar (Oxoid CM107) was used for the purposes of isolating coliform bacteria. Red violet colored colonies of 2-3 mm diameter were counted after 24 hours of incubation at $37^{\circ} \mathrm{C}$, which was realized after inoculation with double layer pour plate inoculation method [7]. TBX agar (Oxoid CM945) was used for the purposes of Escherichia coli isolation. After 4 hours of incubation at $30{ }^{\circ} \mathrm{C}$ and 18 hours of incubation at $44{ }^{\circ} \mathrm{C}$, green colored colonies were evaluated. Serologic tests were performed on all Escherichia coli strains, using E. coli 0157 (Oxoid DR120M) test kit [8]. In order to count StaphylococcusMicrococcus spp., 48 hours of incubation at $37{ }^{\circ} \mathrm{C}$ was applied in the egg yolk telluride emulsion (Oxoid SR54) added Baird Parker Agar Base (Oxoid CM275) medium [7]. Potato Dextrose Agar (Oxoid CM139) was used for the purposes of mold\&yeast isolation. The counting was achieved after 5 days of incubation at $25^{\circ} \mathrm{C}$ [6]. In order to determine the sulfite reducing anaerobic bacteria, Sulfite Polymyxin Sulphadiazine Agar (Merck 1.10235) was used. After culturing through roll tube method, 24 hours incubation at $37^{\circ} \mathrm{C}$ was applied. The black colonies that were formed with irregular edges in the tubes were taken into examination [7]. Of each dilution prepared for Yersinia enterocolitica, $0.1 \mathrm{~mL}$ was spread over selective agar plates (CIN medium, Oxoid CM653) and incubated for $48 \mathrm{~h}$ at 25 ${ }^{\circ} \mathrm{C}$. Plates with presumptive positive $Y$. enterocolitica colonies (dark red eye surrounded by a transparent border) were confirmed with biochemical tests $[9,10]$.

Twenty-five grams of turkey meat sample was weighed and $225 \mathrm{~mL}$ of buffered peptone water (Merck 1.07228) was added and incubated for $16-20 \mathrm{~h}$ at $35-37{ }^{\circ} \mathrm{C}$ for preenrichment of Salmonella spp. One milliliter of the mixture was transferred to $10 \mathrm{~mL}$ Rappaport and Vassiliadis Broth (Merck 1.07700) and incubated for 13-24 h at $42{ }^{\circ} \mathrm{C}$. Another $1 \mathrm{~mL}$ of the mixture was transferred to $10 \mathrm{~mL}$ of selenite cystine broth (Merck 1.07709) and incubated for $24 \mathrm{~h}$ at $35-37{ }^{\circ} \mathrm{C}$ for selective enrichment. Modified brilliant green agar (Oxoid CM329) and Salmonella-
Shigella agar (Merck 1.07667) were used as selective agar medium. After incubation for $24 \mathrm{~h}$ at $35-37{ }^{\circ} \mathrm{C}$, biochemical tests were performed for typical colonies and final diagnosis was made by Salmonella latex test (Oxoid FT203) [11].

$225 \mathrm{~mL}$ of Listeria enrichment broth (Oxoid CM862) was added to $25 \mathrm{~g}$ of turkey meat and incubated for both 24 and $48 \mathrm{~h}$ at $30 \circ \mathrm{C}$ for pre-enrichment of L. monocytogenes. Streaking was performed on Listeria selective agar (Oxford formulation, Oxoid CM856) from pre-enrichment and incubated for $48 \mathrm{~h}$ at $35{ }^{\circ} \mathrm{C}$. Typical colonies were purified at tryptic soy agar (Merck 1.05458). Biochemical and serological tests were carried out for the identification of $L$. monocytogenes [6].

\subsection{Determination of Species in Samples by ELISA Method}

The determination of species on the samples of frozen turkey meats put into sale was made by using ELISA kits produced specifically for turkey. In the analyses, ELISA Technologies Inc. Company's Cooked Turkey Species (Cat No: 510671) kits were used. All the analyses were performed in accordance with the procedure suggested by the producer [12].

\section{Results and Discussion}

Total mesophilic aerobic bacteria, coliforms, Escherichia coli, Staphylococcus- Micrococcus spp., mould\&yeast, Yersinia enterocolitica and sulfite reducing anaerobic bacteria numbers in frozen turkey meats put into sale in Diyarbakır City are given in Table 1. The existence of Salmonella spp. and Listeria monocytogenes pathogens in the samples analyzed are shown at Table 2.

By applying ELISA method, which sort of poultry the sample belongs searched and the results are given at Table 3 .

In this study, the turkey meat samples were examined with respect to the microorganisms which are the indicator of the hygienic quality and may cause risks on public health. Salmonella spp., Listeria monocytogenes, E. coli, coliform bacteria, Staphylococcus-Micrococcus spp., Yersinia enterocolitica, mould\&yeast, and sulfite reducing anaerobic bacteria contamination rates were found to be respectively $\% 3.63, \% 17.27, \% 39.09, \% 68.00, \% 81.81, \% 6$ $1.81, \% 88.18$ and $\% 10.90$ in the samples analyzed. Also, determination of meat species was carried out, and it was confirmed that all the samples were of turkey meat.

Since the studies on the microbiological quality of the frozen turkey meats are very limited, in the discussion, comparisons were made with other turkey meats.

The existence of coliform bacteria in foodstuff is the indicator of bad sanitation conditions [15]. Çolak et al.[4] determined the number of coliform bacteria $3 \log _{10} \mathrm{cfu} / \mathrm{g}$ in their study on cubed turkey meat. Ergönül [14], in his study, reported the coliform and fecal coliform numbers as $<9$ EMS/g. In our study, it was determined that, $68.18 \%$ of the 
meats were contaminated by coliform bacteria at a level of $2.7 \times 10^{4} \mathrm{cfu} / \mathrm{g}$, and $39.09 \%$ of the meats were contaminated by $E$. coli at a level of $1.1 \times 10^{3} \mathrm{cfu} / \mathrm{g}$. These results are higher than the findings of other researchers.

Table 1. Presence of microorganisms in the turkey meat samples (cfu/g)

\begin{tabular}{|c|c|c|c|c|c|c|}
\hline \multirow[t]{2}{*}{ Microorganism } & \multicolumn{2}{|c|}{ positive sample } & \multicolumn{3}{|c|}{ contamination rate $(\mathrm{cfu} / \mathrm{g})$} & \multirow[b]{2}{*}{$\mathbf{S D}^{\mathbf{c}}$} \\
\hline & $\mathbf{n}$ & $\%$ & minimum & maximum & average & \\
\hline $\mathrm{TMAB}^{\mathrm{a}}$ & 110 & 100.00 & $1.0 \times 10^{4}$ & $1.7 \times 10^{8}$ & $9.5 \times 10^{6}$ & $2.4 \times 10^{7}$ \\
\hline Coliform & 75 & 68.18 & $1.0 \times 10^{1}$ & $6.9 \times 10^{5}$ & $2.7 \times 10^{4}$ & $9.4 \times 10^{4}$ \\
\hline E. coli & 43 & 39.09 & $1.0 \times 10^{1}$ & $8.5 \times 10^{3}$ & $1.1 \times 10^{3}$ & $2.1 \times 10^{3}$ \\
\hline Staphlococccus-Micrococcus spp. & 90 & 81.81 & $1.0 \times 10^{1}$ & $6.8 \times 10^{5}$ & $3.4 \times 10^{4}$ & $1.0 \times 10^{5}$ \\
\hline Mould\&yeast & 97 & 88.18 & $1.0 \times 10^{2}$ & $2.9 \times 10^{5}$ & $2.2 \times 10^{4}$ & $5.2 \times 10^{4}$ \\
\hline Yersinia enterocolitaca & 68 & 61.81 & $1.0 \times 10^{1}$ & $7.2 \times 10^{5}$ & $3.3 \times 10^{4}$ & $1.1 \times 10^{5}$ \\
\hline $\mathrm{SRAB}^{\mathrm{b}}$ & 12 & 10.90 & $1.0 \times 10^{1}$ & $1.2 \times 10^{2}$ & $4.5 \times 10^{1}$ & $4.5 \times 10^{1}$ \\
\hline
\end{tabular}

${ }^{\mathrm{a}}$ TMAB: Total mesophilic areob bacteriae, ${ }^{\mathrm{b}} \mathrm{SRAB}$ : Sulfite reducing anaerobe bacteria, ${ }^{\mathrm{c}} \mathrm{SD}$ : standart deviation

Table 2. Microbial contamination rates in the turkey meat samples (percent, \%)

\begin{tabular}{lccc}
\hline Microorganism & sample number (n) & \multicolumn{2}{c}{ contamination rate } \\
& & positive (n) & percent (\%) \\
\hline Salmonella spp. & 110 & 4 & 3.63 \\
Listeria spp. & 110 & 19 & 17.27 \\
\hline
\end{tabular}

Table 3. The presence of turkey meat in analyzed samples (percent, \%)

\begin{tabular}{lccc}
\hline & sample & \multicolumn{2}{c}{ positive rate } \\
& number (n) & positive (n) & percent (\%) \\
\hline Turkey meat & 110 & 110 & 100.00 \\
\hline
\end{tabular}

Yeast and mould contamination levels in cubed turkey meat were reported by Çolak et al.[4], as 3.02-3.35 $\log _{10}$ $\mathrm{cfu} / \mathrm{g}$, and by Ergezer [15] on the other hand, as 2.49-3.27 $\log _{10} \mathrm{cfu} / \mathrm{g}$. In our study, mould\&yeast contamination rate was found as $88.18 \%$ and the average number of mould\&yeast was found as $2.2 \times 104 \mathrm{cfu} / \mathrm{g}$. In view of mould\&yeast contamination, the results of our study are higher than those of earlier studies.

Mayrhofer et al.[16] reported Salmonella on only 1 of 262 turkey meat samples and 46 of 281 chicken meat (16.4). In the study of Zhao et al.[17], the existence of Salmonella in turkey meats was determined as $2.6 \%$. Beli et al.[18], in their study conducted in Albania during the years 1996-1998, determined 11 Salmonella of $134(8.2 \%)$ in turkey meat samples. Aslam et al.[19] in their study in Canada, found Salmonella contamination in turkey meats as $27 \%$. Tanoğlu and Gümüşsoy [20] reported that there was no Salmonella spp. determined in turkey drum stick, skin and chest samples in their study. Ergönül [14], in his study on turkey döner kebab, Salmonella spp. could not be determined. According to the Turkish Food Codex Microbiological Criteria Regulation [21], it is required that, in 25 grams of uncooked poultry meats, there should be no Salmonella spp. In addition, $3.63 \%$ of turkey meats analyzed in this study are Salmonella spp. positive and they are not suitable to consume according to the Turkish Food Codex.

In this study, $17.27 \%$ of the 110 samples, Listeria monocytogenes was determined. In a study conducted by Ojeniyi et al.[22] in Denmark at an integrated turkey meat plant, L. monocytogenes was determined as $7.3 \%$ on the foods ready to consume and $17.4 \%$ on uncooked products. In the studies carried out in China and USA, $L$. monocytogenes contamination was determined to be $38 \%$ $[23,24]$; in a study conducted in Greece, however, $L$. monocytogenes was detected as $30.1 \%$ of turkey neck meat samples, and as $19.2 \%$ of turkey breast meat samples [25]. In another studies carried out in Ankara, Turkey, $L$. monocytogenes was found as $13.3 \%$ in fresh brisket, leg and turkey meat cuts and $17.7 \%$ form fresh turkey minced meat samples [26, 27].

Ergönül [14] in the study for his thesis reported that Staphylococcus aureus could not be determined on the sliced kebabs made of turkey meats. Koçyiğit and Karaboz [28], in their study conducted in İzmir on chicken and turkey meats, determined pathogenic Staphylococci in the range of minimum $1.6 \times 10^{3} \mathrm{cfu} / \mathrm{g}$ and maximum $6.6 \times 10^{6} \mathrm{cfu} / \mathrm{g}$ on $100 \%$ of the samples. Hanson et al. [29] determined $S$. aureus contamination level as $19.4 \%$ in turkey meats. On the 52 turkey meat samples put into sale in various markets as a packaged products (39 legs and 13 wings), at a level of $6.3 \times 10^{2} \mathrm{cfu} / \mathrm{g}$ level Staphylococci and Micrococci were determined [30]. In our study, StaphylococccusMicrococcoccus spp. was determined on average $3.4 \times 10^{4}$ $\mathrm{cfu} / \mathrm{g}$ in 90 of 110 samples $(81.81 \%)$. These data are higher than those reported by other researchers.

In a study conducted by Ali and Fung [31], $C$. perfringens was isolated in 40 of 55 turkey minced meat samples (73.0\%). In a study conducted by Erol et al.[32], it was found that $12.2 \%$ of the turkey meat samples was contaminated by $C$. perfringens. Sarıüzel and Erol [33] isolated and identified $C$. perfringens in 58 of 100 turkey minced meat samples. On the samples examined in our study, the rate of sulfite reducing contamination rate $10.90 \%$ and the average number of bacteria $4.5 \times 10^{1} \mathrm{cfu} / \mathrm{g}$ have been found. This value is lower than the results of $C$. perfringens found by other researchers.

On the analyzed turkey meats in this study, existence of 
Yersinia enterocolitica was found at a level of $61.81 \%$ (average $3.3 \times 10^{4} \mathrm{cfu} / \mathrm{g}$ ). Nortje et al.[10] reported the average number of $Y$. enterocolitica as $2.5 \times 102 \mathrm{cfu} / \mathrm{g}$ and the rate of contamination as $15.7 \%$ on broilers. Researchers found $Y$. enterocolitica on 10 of 21 turkey meat samples and 40 of 89 chicken meat samples. These results are lower than those obtained in our study.

\section{Conclusion}

In this study, it was seen that the contamination levels and numbers of the microorganisms in frozen turkey meats are similar to or worse than the fresh (not frozen) turkey meats. The most important reasons of the low hygienic quality in frozen meats were determined as low raw material quality, applications during and before the freezing and failure to follow the food safety conditions in storage of frozen foods. It is concluded that the hygienic quality of the frozen turkey meats put into sale in Diyarbakır City is low, and this situation pose a significant risk on public health. Starting from the farm onwards, conforming to good production and hygienic applications in all the stages of production and storage may be useful to prevent the possible risks.

\section{References}

[1] P.B Addis, "Poultry muscle as food. Bechtel, P (Ed.). Muscle as Food,” Journal Academic Press Inc., London, 1986.

[2] Ö. İșeri, and İ. Erol, "Hindi etinden kaynaklanan başlıca bakteriyel infeksiyon ve intoksikasyonlar," Ankara Üniversitesi Veteriner Fakültesi Dergisi, 56, 2009, pp. 47-54

[3] N. Koyubenbe, and Y. Konca, “Türkiye ve Avrupa Birliği’nde hindi eti üretimi, tüketimi ve politikaları," Ege Üniversitesi Ziraat Fakültesi Dergisi, 47(2), 2010, pp. 201-209

[4] H. Çolak, G. Ugurluay, B. Nazlı, and B. Bingöl, "Paketlemede kullanılan nem tutucu filtrelerin hindi etinin raf ömrü üzerine etkisi," İstanbul Üniversitesi Veteriner Fakültesi Dergisi, 37 (2), 2011, pp. 107-116

[5] N.D. Ayaz, "Hindi kıymalarında Listeria monocytogenes' in immuno manyetik separasyon ve PCR ile tanis1 ve antibiyotik duyarlılıklarının saptanması," Doktora tezi. Ankara Üniversitesi Sağlık Bilimleri Enstitüsü, Ankara, 2008. (in Turkish)

[6] BAM: Bacteriological Analytical Manual. AOAC Int., Gaithersburg, 2001.

[7] W.F. Harrigan, "Laboratory Methods in Food Microbiology,” Academic Press, New York, 1998

[8] The Oxoid Manual, "The Oxoid Manual," 9th ed. Published by Oxoid Limited, Hampshire, England, 2006

[9] J.C. Freeley, W.H. Lee, and G.K. Morris, "Yersina enterocolitica," In Compendium of Methods for the Microbiological Examination of Foods (Ed. M. L. Speck) pp. 351-357. American Public Health Association, Washington D.C., 1976
[10] G.L. Nortje, S.M. Vorster, R.P. Greebe, and P.L. Steyn, "Occurrence of Bacillus cereus and Yersinia enterocolitica in South African retail meats," Food Microbiology, 16, 1999, pp. 213-217

[11] ISO: Microbiology General Guide on Methods for the Detection of Salmonella. Draft International Standard ISO/DIS 6579, International Organization for Standardization, Geneva, Switzerland, 1988.

[12] Elisa-tek, ELISA Technologies, Inc. 2501 NW 66th Court, Gainesville, FL 32653 USA.http://www.elisa-tek.com/wpcontent/uploads/2011/11/ELISA-CMS-Data-Sheet-2011.pdf. Date of access: 23.03.2013.

[13] A.G. Sezen, "Piyasada satısa sunulan taze kanatlı eti preparatlarının son kullanma tarihlerinde duyusal ve mikrobiyolojik kaliteleri," Doktora Tezi, İstanbul Üniversitesi Sağlık Bilimleri Enstitüsü, İstanbul, 2007

[14] B. Ergönül, "Dondurarak Depolama Süresinin Çiğ Hindi Dönerlerinin Kimyasal, Mikrobiyolojik ve Duyusal Kalitesi Üzerine Etkisi," Yüksek Lisans Tezi. Celal Bayar Üniversitesi Fen Bilimleri Enstitüsü, Manisa, 2004

[15] H. Ergezer, "Değişik yöntemlerle marine edilmiş kanatlı etlerinin kimyasal, mikrobiyolojik, tekstürel ve duyusal özellikleri," Yüksek Lisans Tezi, Pamukkale Üniversitesi Fen Bilimleri Enstitüsü, Denizli, 2005

[16] S. Mayrhofer, P. Paulsen, F.J.M. Smulders, and F. Hilbert, "Antimicrobial resistance profile of five major food-borne pathogens isolated from beef, pork and poultry," International Journal of Food Microbiology, 97, 2004, pp. 23-29

[17] C. Zhao, B. Ge, J. De Villena, R. Sudler, E. Yeh, S. Zhao, and D.G. White, "Prevalence of Campylobacter spp., Escherichia coli, and Salmonella serovars in retail chicken, turkey, pork, and beef from the Greater Washington, D.C., Area," Applied and Environmental Microbiology, 67(12), 2001, pp. 5431-5436

[18] E. Beli, A. Telo, and E. Duraku "Salmonella serotypes isolated from turkey meat in Albania," International Journal of Food Microbiology, 63, 2001, pp. 165-167

[19] M. Aslam, S. Checkley, B. Avery, G. Chalmers, V. Bohaychuk, G. Gensler, R. Reid-Smith, and P. Boerlin, "Phenotypic and genetic characterization of antimicrobial resistance in Salmonella serovars isolated from retail meats in Alberta, Canada," Food Microbiology, 32 (1), 2012, pp. 110-117

[20] B. Tanoğlu, and S. Gümüșsoy, “ Erzincan Garnizonunda tüketime sunulan tavuk ve hindi etlerinden konvansiyonel kültür ve moleküler (pzr) metodla Salmonella spp. teşhisi," Sağlık Bilimleri Dergisi (Journal of Health Sciences), 17(3), 2008, 150-155

[21] TFC "Regulation on Microbiological Criteria of Turkish Food Codex,” Official gazette (29.12.2011-28157), Ankara, 2011

[22] B. Ojeniyi, J. Christensen, and M. Bisgaard, "Comparative investigations of Listeria monocytogenes isolated from a turkey processing plant, turkey products, and from human cases of listeriosis in Denmark," Epidemiology and Infection, 125 (2), 2000, pp. 303-308

[23] H.C. Wong, W.L. Chao, and S.J. Lee, "Incidence and characterization of Listeria monocytogenes in foods available in Taiwan," Applied and Environmental Microbiology, 56, 1990, pp. 3101-3104 
[24] I.V. Wesley, K.M. Harmon, J.S. Dickson, and A.R. Schwartz, "Application of a multiplex polymerase chain reaction assay for the simultaneous confirmation of Listeria monocytogenes and other Listeria species in turkey sample surveillance, Journal of Food Protection, 65, 2002, pp. 780-785

[25] J. Samelis, and J. Metaxopoulos, "Incidence and principal sources of Listeria spp. and Listeria monocytogenes contamination in processed meats and a meat processing plant," Food Microbiology, 16, 1999, pp. 465-477

[26] N.D. Ayaz, and I. Erol, "Hindi kıymalarından Listeria monocytogenes'in immuno manyetik separasyon ile saptanmas1 ve izolatların antibiyotik duyarlılıklarının belirlenmesi," 2. Ulusal Veteriner Gida Hijyeni Kongresi Bildiri Kitabl, pp. 108-115, İstanbul, 2006

[27] I. Erol, F.S. Bilir Ormanc1, N.D. Ayaz, Ö. İșeri, and D. Sarıüzel, "Hindi etlerinden izole edilen Salmonella spp., Listeria monocytogenes ve Clostridium perfringens izolatlarının antibiyotik dirençliliğinin belirlenmesi," 2 . Ulusal Veteriner Gida Hijyeni Kongresi Bildiri Kitabı, pp. 116-123, İstanbul, 2006

[28] A. Koçyiğit, and İ. Karaboz, "İzmirde çeşitli marketlerde satışa sunulan tavuk ve hindi etlerinde Staphylococcus aureus aranmas1, sayım1 ve tanımlanmas1," Gida, 30(4), 2005, 281-285
[29] B.M. Hanson, A.E. Dressler, A.L. Harper, R.P. Scheibel, S.E. Wardyn, L.K. Roberts, J.S. Kroeger, and T.C. Smith, "Prevalence of Staphylococcus aureus and methicillinresistant Staphylococcus aureus (MRSA) on retail meat in Iowa," Journal of Infection and Public Health, 4(4), 2011, $169-174$

[30] S. Kılıç, and Ö. Küplülü, "Detection the enterotoxin producing capacity of coagulase positive Staphylococcus by EIA (Enzyme Immuno Assay) isolated from turkey meat" Ankara Üniversitesi Veteriner Fakültesi Dergisi, 56, 2009, pp. $183-186$

[31] M.S. Ali, and D.Y.C. Fung, "Occurrence of Clostridium perfringens in ground beef and ground turkey evaluated by three methods," Journal of Food Safety, 11 (3), 1990, 197-203

[32] İ. Erol, M. Göncüoğlu, N.D. Ayaz, F.S. Bilir Ormancı, and G Hildebrandt, "Molecular typing of Clostridium perfringens isolated from turkey meat by multiplex PCR," Letters in Applied Microbiology, 47(1), 2008, pp. 31-34

[33] D. Sarıüzel, and İ. Erol, "Occurrence of Clostridum perfringens in ground turkey and investigation of the isolates for the presence of cpe by PCR," In: Proceedings of 14th World Veterinary Poultry Congress. pp. F14-605 (502), 2005 